This is an Open Access article distributed under the terms of the Creative Commons Attribution 4.0 International License which permits unrestricted non-commercial use, distribution, and reproduction in any medium provided the original work is properly cited

\title{
Factors Affecting Anxiety in Hypertension Patients at M.Th. Djaman General Hospital Sanggau District, West Borneo 2018
}

\author{
Stepanus Maman Hermawan ${ }^{1 *}$, Aurelia Citra Silalahi ${ }^{2}$, \\ Lydia Moji Lautan ${ }^{3}$
}

Lecturer in Nursing Department Akademi Keperawatan Dharma Insan

*Corresponding: Stepanusutd@gmail.com

\begin{abstract}
Hypertension is a condition where a person experiences an increase in blood pressure above average on a blood pressure check. Based on the JNC-VII criteria applied in Indonesia Hypertension is expressed as blood pressure equal to or more than $140 / 90 \mathrm{mmHg}$. This research aims to identify the factors that most influence hypertensive anxiety patients at the General Hospital M.Th. Djaman Sanggau. This research is quantitative research using descriptive analysis research method with Cross-Sectional approach. This study using purposive sampling involved 45 samples of hypertensive patients undergoing treatment at the hospital M.Th.Djaman Sanggau. Data analysis using Chi-Square. The result is there was no relationship between age and anxiety levels of hypertension patients $p=0.246(p>0.05)$, there was no relationship between sex with anxiety levels of hypertension patients $p=0.495(p>0.05)$, there was a relationship between the level of education and the level of anxiety of patients hypertension $p=0.011(p<0.05)$. There is a relationship between work with the anxiety level of hypertension patients $p=0,000(p<0,05)$. There is a significant relationship between the level of knowledge with the level of anxiety of patients with hypertension $\mathrm{p}=0.001(\mathrm{p}<0.05)$. Stress is directly related to an increase in blood pressure so that someone needs to do counseling related to his condition to reduce anxiety, and need changes from individuals to change the risk factors for hypertension with healthy lifestyles such as fruit, vegetables, exercise regularly and reduce excessive consumption of calories and fat.
\end{abstract}

Keywords: hypertension, level of anxiety, patient characteristic

\section{Background}

The National Health System strives for health development in Indonesia to be directed towards achieving a higher level of health, which enables humans to live more productively both socio-economic. Increased socio-economic status, health services, lifestyle changes, then in Indonesia there is a shift in the pattern of diseases from infectious diseases to non-communicable diseases and is known as the epidemiological transition. The trend of increasing prevalence of non-communicable diseases is hypertension(1,2). Hypertension has become a significant public health problem in Indonesia and several countries in the world. World health organization (WHO) estimated that one billion suffered hypertension and was predicted to be 1.15 billion cases in 2025 . While $80 \%$ were retained in the developing country (3). 
Hypertension is categorized as the silent disease because the patient does not know he has hypertension before checking his blood pressure. Hypertension is also often referred to as the "silent killer" because a person can suffer from hypertension for years without realizing it until there is damage to vital organs that are quite heavy which can even bring death $(4,5)$. Hypertension can be defined as a condition which is increasing the level of blood pressure from the normal line(6). In Indonesia, the criteria of hypertension followed by The Joint National Committee on prevention, detection, evaluation, and treatment requirements on High Blood Pressure VII (JNCVII) blood pressure which is more than or equal with $140 / 90 \mathrm{mmHg}$ is hypertension(2).

Several factors associated with hypertension including; obesity, age, salt intake, cigarettes, coffee, and stress. Stress becomes a crucial point since it could affect on abnormalities of body hormone such as epinephrine(7). Intrinsic factors that can affect a person's level of anxiety include: age, gender, level of education, level of individual knowledge, and work can also affect own anxiety levels $(8,9)$.

Based on preliminary studies conducted on hypertension patients at the M.Th. Djaman Hospital Sanggau District of 10 respondents there were five with a lack of knowledge and four patients with moderate anxiety and six patients with mild anxiety levels. This research needs to be done considering that besides the high incidence of hypertension, patients are also increasingly aware of periodic check-ups at health facilities and making changes to healthy lifestyles such as eating fruits and vegetables, regular and measurable exercise and avoiding excessive consumption of calories and fat.

\section{Objective}

The research aimed to identify the factors that most influence hypertensive anxiety patients at the General Hospital M.Th. Djaman Sanggau

\section{Method}

The research design of this study using a cross-sectional to determine factors associated with hypertension. Purposive sampling was conducted to select 45 samples based on the inclusion criteria. The inclusion criteria including a) Hypertension patients without comorbidities diseases including Diabetes Mellitus, Stroke, Heart Diseases, and Kidney Diseases, b) Willingness to participate in this study, c) Patients aged $\geq 19$ years, and d) At least have passed a primary school.

Instruments were used to measure the outcomes including Hamilton Rating Scale for Anxiety (HRS-A)(10). The components measured in this HRS-A are feelings of anxiety, tension, fear, sleep disturbances, intelligence disorders, feelings of depression (moody), somatic or physical (muscle) symptoms, somatic or physical (sensory) symptoms, cardiovascular symptoms, respiratory symptoms, gastrointestinal symptoms, urogenital symptoms, autonomic symptoms, and behavior $(11,12)$.

This measuring instrument consists of 14 groups of symptoms; each group has broken down with more specific symptoms. Each symptom group is given a score (score) of 0-4, which means it is a value of 0 if there are no symptoms or complaints, value 1 if symptoms are mild or one of the signs is present, value 2 if symptoms are moderate or half of the symptoms, value 3, if symptoms are severe or more than half of the symptoms are present, and value 4 if symptoms are severe or all of the symptoms are current $(13,14)$. 
Test the validity of the questionnaire the level of knowledge carried out by researchers in health facilities by the location of the study to 30 respondents. The results of the validity test of the knowledge variable about the anxiety of hypertensive patients have obtained 20 valid questions with a calculated value of $0.349-0.632$. The reliability test results obtained Alpha values for the patient's knowledge of hypertensive patient anxiety by 0.831 . So the question instrument in this study is declared reliable because the value of Alpha Cronbach is more than $0.60(15,16)$.

\section{Results}

\subsection{Characteristics of hypertensive patients}

Table 1 showed that the majority of respondents aged 56-65 years 22 people (48.7\%), results also showed that respondents who were male were 16 respondents (35.6\%) and women were 29 respondents (64.4\%). The majority of respondents' educational backgrounds appear in this study were Primary and secondary education (Elementary, junior high school, Senior High School) with 24 respondents (53.3\%). The majority of the working status of respondents in this study did not work with 28 respondents $(62.2 \%)$. The majority of respondents' knowledge in this study was good with 27 respondents (60\%). The results showed that respondents who had no anxiety 15 respondents (33.3\%), respondents with mild anxiety level 12 respondents $(26.7 \%)$, respondents with moderate anxiety level 12 respondents $(26.7 \%)$ and respondents with severe anxiety levels six respondents (13.3\%).

Table 4.1 characteristic of hypertensive patients

\begin{tabular}{|c|c|c|c|}
\hline \multicolumn{2}{|c|}{ Characteristics of respondents } & $\mathrm{n}$ & $\%$ \\
\hline \multirow[t]{5}{*}{ Age } & $26-35$ years (early adult) & 4 & 8.4 \\
\hline & $36-45$ years old (late adult) & 3 & 11 \\
\hline & $46-55$ years (early elderly) & 13 & 28.8 \\
\hline & 56-65 years (late elderly) & 22 & 48.7 \\
\hline & $>65$ tahun (elderly) & 3 & 6.6 \\
\hline \multirow[t]{2}{*}{ Gender } & Male & 16 & 35.6 \\
\hline & Female & 29 & 64.4 \\
\hline \multirow[t]{2}{*}{ Educational Background } & $\begin{array}{l}\text { Primary and secondary education (Elementary, } \\
\text { junior high school, Senior High School) }\end{array}$ & 24 & 53.3 \\
\hline & College (University) & 21 & 46.7 \\
\hline \multirow[t]{2}{*}{ Working Status } & Work & 17 & 37.8 \\
\hline & Not work & 28 & 62.2 \\
\hline \multirow[t]{2}{*}{ Knowledge } & Enough & 18 & 40 \\
\hline & Good & 27 & 60 \\
\hline \multirow[t]{4}{*}{ Level of anxiety } & None & 15 & 33.3 \\
\hline & Mild Anxiety & 12 & 26.7 \\
\hline & Moderate Anxiety & 12 & 26.7 \\
\hline & Severe Anxiety & 6 & 13.3 \\
\hline
\end{tabular}

\subsection{Relationship between age with anxiety}

The relationship between age and anxiety (table 2) shows the majority of respondents aged 56-65 years (late elderly), i.e. 22 respondents (48.9\%) consisting of 7 respondents $(15.6 \%)$ none anxiety, 5 respondents $(11.1 \%)$ mild anxiety, 6 respondents (13.3\%) moderate anxiety, and 4 respondents (8.9\%) severe anxiety. The results 
indicated there was no significant relationship between age and anxiety of hypertensive patients $(p=0.246)$.

Table 4.2 relation of age with levels of anxiety

\begin{tabular}{|c|c|c|c|c|c|c|c|}
\hline \multirow[b]{2}{*}{ No } & \multirow[b]{2}{*}{$\begin{array}{l}\text { Category Age } \\
\text { Respondents }\end{array}$} & \multicolumn{4}{|c|}{ Category Level Respondents Anxiety } & \multirow[b]{2}{*}{ Total } & \multirow{2}{*}{$\begin{array}{c}\text { P- } \\
\text { Value }\end{array}$} \\
\hline & & None & $\begin{array}{c}\text { Mild } \\
\text { Anxiety }\end{array}$ & $\begin{array}{l}\text { Moderate } \\
\text { Anxiety }\end{array}$ & $\begin{array}{l}\text { Severe } \\
\text { Anxiety }\end{array}$ & & \\
\hline 1. & $26-35$ years & $1(2.2 \%)$ & $1(2.2 \%)$ & $2(4.4 \%)$ & $0(0)$ & $4(8.9 \%)$ & 0.246 \\
\hline 2. & $36-45$ years & $3(6.7 \%)$ & $0(0 \%)$ & $0(0 \%)$ & $0(0 \%)$ & $3(6.7 \%)$ & \\
\hline 3. & 46 - 55 years & $3(6.7 \%)$ & $5(11.1 \%)$ & $4(8.9 \%)$ & $1(2.2 \%)$ & $13(28.9 \%)$ & \\
\hline 4. & 56 - 65 years & $7(15.6 \%)$ & $5(11.1 \%)$ & $6(13.3 \%)$ & $4(8.9 \%)$ & $22(48.9 \%)$ & \\
\hline 5. & $>65$ years & $1(2.2 \%)$ & $1(2.2 \%)$ & $0(0 \%)$ & $1(2.2 \%)$ & $3(6.6 \%)$ & \\
\hline & Total & $15(33.3 \%)$ & $12(26.7 \%)$ & $12(26.7 \%)$ & $6(13.3 \%)$ & $45(100 \%)$ & \\
\hline
\end{tabular}

\subsection{Relationships gender with anxiety}

The relationship between gender and anxiety (table 3) shows the majority of respondents were female 29 respondents (64.4\%) consisting of 7 respondents $(15.6 \%)$ none anxiety, 9 respondents $(20 \%)$ mild anxiety, 10 respondents $(22,2 \%)$ moderate anxiety and 3 respondents $(6.7 \%)$ severe anxiety. The results indicated that there was no significant relationship between sex and anxiety in hypertensive patients $(p=0.495)$.

Table 4.3 Gender relations with anxiety levels

\begin{tabular}{|c|c|c|c|c|c|c|c|}
\hline \multirow[b]{2}{*}{ No } & \multirow[b]{2}{*}{$\begin{array}{c}\text { Gender } \\
\text { Respondents }\end{array}$} & \multicolumn{4}{|c|}{ Category Level Respondents Anxiety } & \multirow[b]{2}{*}{ Total } & \multirow[b]{2}{*}{ P-Value } \\
\hline & & None & $\begin{array}{l}\text { Mild } \\
\text { Anxiety }\end{array}$ & $\begin{array}{l}\text { Moderate } \\
\text { Anxiety }\end{array}$ & $\begin{array}{c}\text { Moderate } \\
\text { Anxiety }\end{array}$ & & \\
\hline 1. & Female & $7(15.6 \%)$ & $9(20 \%)$ & $10(22.2 \%)$ & $3(6.7 \%)$ & $29(64.4 \%)$ & 0.495 \\
\hline \multirow[t]{2}{*}{2.} & Male & $8(17.8 \%)$ & $3(6.7 \%)$ & $2(4.4 \%)$ & $3(6.7 \%)$ & $16(35.6 \%)$ & \\
\hline & Total & 15 (33.3\%) & $12(26.7 \%)$ & $12(26.7 \%)$ & $6(13.3 \%)$ & $45(100 \%)$ & \\
\hline
\end{tabular}

\subsection{Relationship educational background with anxiety}

The relationship between education and anxiety (table 4) shows the majority of the education background of respondents primary and secondary education 24 respondents (53.3\%), consisting of 3 respondents (6.7\%) none anxiety, 6 respondents (13.3\%) anxiety mild, 9 respondents (20\%) moderate anxiety and 6 respondents $(13.3 \%)$ severe anxiety. The results indicated that there was a significant relationship between education and anxiety in hypertensive patients $(p=0.011)$

Table 4.4 Relates the level of educational background to anxiety

\begin{tabular}{|c|c|c|c|c|c|c|c|}
\hline \multirow[b]{2}{*}{ No } & \multirow[b]{2}{*}{$\begin{array}{l}\text { Educational } \\
\text { Background }\end{array}$} & \multicolumn{4}{|c|}{ Category Level Respondents Anxiety } & \multirow[b]{2}{*}{ Total } & \multirow[b]{2}{*}{ P-Value } \\
\hline & & None & $\begin{array}{c}\text { Mild } \\
\text { Anxiety }\end{array}$ & $\begin{array}{l}\text { Moderate } \\
\text { Anxiety }\end{array}$ & $\begin{array}{l}\text { Severe } \\
\text { Anxiety }\end{array}$ & & \\
\hline 1. & $\begin{array}{l}\text { Primary and } \\
\text { secondary } \\
\text { education }\end{array}$ & $3(6.7 \%)$ & $6(13.3 \%)$ & $9(20 \%)$ & $6(13.3 \%)$ & $24(53.3 \%)$ & 0.011 \\
\hline \multirow[t]{2}{*}{2.} & Collage & $12(26.7 \%)$ & $6(13.3 \%)$ & $3(6.7 \%)$ & $0(0)$ & $21(46.7 \%)$ & \\
\hline & Total & $15(33.3 \%)$ & $12(26.7 \%)$ & $12(26.7 \%)$ & $6(13.3 \%)$ & $45(100 \%)$ & \\
\hline
\end{tabular}




\subsection{Relationship working status relationships with anxiety}

The relationship between working status and anxiety level (table 5) shows the majority of respondents did not work 31 respondents $(68.9 \%)$, consisting of 3 respondents (6.7\%) none anxiety, 12 respondents $(26.7 \%)$ mild anxiety, 10 respondents $(22.2 \%)$ moderate anxiety and 6 respondents $(13.3 \%)$ severe anxiety. The results indicated that there was a significant relationship between working status and anxiety in hypertensive patients $(p=0,000)$.

Table 4.5 related the working status with anxiety

\begin{tabular}{|c|c|c|c|c|c|c|c|}
\hline \multirow[b]{2}{*}{ No } & \multirow[b]{2}{*}{ Working Status } & \multicolumn{4}{|c|}{ Respondent Anxiety Level Category } & \multirow[b]{2}{*}{ Total } & \multirow[b]{2}{*}{ P-Value } \\
\hline & & None & $\begin{array}{c}\text { Mild } \\
\text { Anxiety }\end{array}$ & $\begin{array}{l}\text { Moderate } \\
\text { Anxiety }\end{array}$ & $\begin{array}{l}\text { Severe } \\
\text { Anxiety }\end{array}$ & & \\
\hline 1. & Not working & $3(6,7 \%)$ & $12(26,7 \%)$ & $10(22,2 \%)$ & $6(13,3 \%)$ & $31(68,9 \%)$ & 0,000 \\
\hline \multirow[t]{2}{*}{2.} & Work & $12(26,7 \%)$ & $0(0)$ & $2(4,4 \%)$ & $0(0)$ & $14(31,1 \%)$ & \\
\hline & Total & $15(33,3 \%)$ & $12(26,7 \%)$ & $12(26,7 \%)$ & $6(13,3 \%)$ & $45(100 \%)$ & \\
\hline
\end{tabular}

\subsection{Relationship knowledge relationship with anxiety}

The relationship between knowledge and anxiety (table 6) shows the majority of respondents with good knowledge 27 respondents (60\%), consisting of 14 respondents (31.1\%) none anxiety, seven respondents (15.6\%) mild anxiety, six respondents $(13,3 \%)$ severe anxiety. The results indicated that there was a significant relationship between knowledge and anxiety of hypertensive patients $(p=0,000)$.

Table 4.6 related to knowledge and anxiety

\begin{tabular}{|c|c|c|c|c|c|c|c|}
\hline \multirow[b]{2}{*}{ No } & \multirow[b]{2}{*}{ Knowledge } & \multicolumn{4}{|c|}{ Category level respondents anxiety } & \multirow[b]{2}{*}{ Total } & \multirow[b]{2}{*}{ P Value } \\
\hline & & None & $\begin{array}{c}\text { Mild } \\
\text { Anxiety }\end{array}$ & $\begin{array}{l}\text { Moderate } \\
\text { Anxiety }\end{array}$ & $\begin{array}{l}\text { Severe } \\
\text { Anxiety }\end{array}$ & & \\
\hline 1. & Enough & $1(2.2 \%)$ & $5(11.1 \%)$ & $6(13.3 \%)$ & $6(13.3 \%)$ & $18(40 \%)$ & \multirow[t]{2}{*}{0.020} \\
\hline & Good & $14(31.1 \%)$ & $7(15.6 \%)$ & $6(13.3 \%)$ & $0(0)$ & $27(60 \%)$ & \\
\hline & Total & $33.3 \%$ & $26.7 \%$ & $26.6 \%$ & 13.3 & 100 & \\
\hline
\end{tabular}

\section{DISCUSSION}

\subsection{Description anxiety respondents hypertension}

The anxiety of hypertension patients that most experience anxiety both mild, moderate and severe. It is due to several factors such as knowledge, educational background and lack of information about hypertension in the respondents. Anxiety arises because of something that is not clear or unknown so that feelings that are not calm, worry, or fear arise $(8,17)$. Some studies are in line stating that anxiety is a manifestation of psychological behavior and various behavioral patterns that occur from feelings of anxiety and subjective tension $(18,19)$.

Anxiety is the only psychological factor that affects hypertension. Anxiety or psychosocial stress can increase blood pressure $(20,21)$. Several studies compared the blood pressure of respondents suffering from anxiety with respondents who did not suffer from anxiety, obtained higher blood pressure results in the group of patients with anxiety than those who were not anxious $(22,23)$. 
Anxiety and stress can cause stimulation of the sympathetic nervous system, which increases blood frequency, cardiac output, and peripheral vascular resistance $(24,25)$. Sympathetic effects increase blood pressure, but also mental tension (feeling depressed, moody, confused, anxious, pounding, feeling angry, resentment, fear, guilt) can stimulate the kidney glands to release adrenal hormones and accelerate the heart beat faster and stronger, so that blood pressure will increase. If stress lasts long enough, the body tries to make adjustments so that organic abnormalities or pathological changes arise.

\subsection{Relationship age and anxiety respondents of hypertensive patients}

In this study, it can be concluded that there is no significant relationship between age and anxiety level in hypertension patients with Pearson Correlation values obtained $p=0.246$ ( $\mathrm{p}>0.05$ ). Most respondents aged 56-65 years who experience anxiety. Some studies similar to the results of this study are in line which shows that there is no relationship with age level $(26,27)$. The results of this study are consistent with the relationship between age and anxiety with a value of $0.267>0.05$ so that there is no relationship between age and anxiety $(9,28)$.

Anxiety disorders can occur at all ages, more often in adulthood and most anxiety occurs at the age of 21-45 years $(29,30)$. Age affects a person's psychology, the higher the age, the better the level of one's emotional maturity and ability to deal with various problems. This is because age relates to experience and views of something, the more a person ages, the more mature the process of thinking and acting on something.

\subsection{Relationship gender and anxiety of hypertensive patients}

In this study resulted that there was no significant relationship between gender with anxiety levels of hypertension patients with Kolmogorov Smirnov $p=0.495$ ( $p>0.05)$. This study occurred in most women experiencing anxiety. The results of this study are consistent with the results of several studies that gender is not related to the level of significance of patients with a significance value of 0.193 for gender $(26,27)$. The results of this study are in line with the results of several studies; there is a relationship between gender and anxiety with the p-value of $0.073>0.05$, so the conclusion is that there is no relationship between gender and anxiety $(23,31)$. Factors that influence anxiety include gender, this study states there is no relationship between gender and anxiety, but basically, women tend to have the anxious attitude because women use their feelings more in responding to all forms of change that occur. Hormonal factors also affect stress levels in women because women tend to have hormones that are not stable than men so that women have more emotional qualities than men.

\subsection{Relationship educational background and anxiety of hypertensive patients}

In this study, it was concluded that there was a significant relationship between the level of educational background and the level of anxiety in hypertensive patients with Kolmogorov Smirnov $p=0.011(\mathrm{p}<0.05)$. Statistical test results showed a significant relationship between the educational background with anxiety in patients with hypertension ( $p$-value $=0,000$ ). In this study most respondents with primary and secondary education level experienced anxiety. The results of this study are in line with the results of several studies that there is a significant relationship between the back of maternal education and the anxiety level $(32,33)$. Education is a factor that can affect the level of anxiety of someone who has hypertension. In addition to formal training, 
individuals who experience hypertension can also increase their knowledge through existing media by the times such as books, magazines, posters, leaflets, and the internet related to hypertension.

\subsection{Relationship working status and anxiety of hypertensive patients}

This study concluded that there was a significant relationship with the anxiety level of patients with hypertension with Kolmogorov Smirnov $p=0,000(\mathrm{P}<0.05)$. In this study most respondents who did not work experienced anxiety. Results of the correlation between working status and anxiety were a visible relationship between the two variables, meaning that respondents who do not work more anxiety than respondents working. Statistical test results that there is a significant relationship between working status with anxiety in patients with hypertension $(p=0.001)$.

The results of this study are the results of several reviews stating that there is a significant relationship between job status and anxiety level $p=0.016$ ( $p$ $<0.05)(29,34)$. The results of this study are in line with the results of several studies on the relationship between work status and anxiety with the results of $p=0.01>0.05$ so the conclusion is the relationship between work and anxiety $(9,28)$.

In research respondents who work less experience anxiety than respondents do not work. Some studies suggest that someone who works in the formal sector has better access to various information, including health $(19,35)$. When linked, someone who works becomes more comfortable to get information about their health and illness, with the information they get can increase their knowledge about hypertension which in turn can reduce anxiety and even eliminate anxiety the disease. Respondents who work tend to have good knowledge and are easier to understand the condition so that they can carry out the necessary coping mechanisms and can minimize their anxiety. In addition, a study also reported that high activity with relaxation progressive muscle was associated with decreasing blood pressure and cholesterol level (36).

\subsection{Relationship knowledge and anxiety respondents hypertension}

The results of this study concluded that there was a significant relationship between knowledge and anxiety in patients with hypertension. The results of the study that most of the respondents who had experience enough. The results of the correlation test between the level of knowledge with the level of anxiety of the respondents that the relationship is strong and has a definite pattern, meaning that the enough the respondent's knowledge about hypertension will increase the anxiety experienced respondents.

The results of this study are in line with several studies stating that there is a significant relationship between knowledge and situation(29,37). The above is closely related to public awareness about hypertension if individual knowledge about hypertension will motivate patients to participate in modifying lifestyles such as losing weight, reducing alcohol consumption, regular exercise and increased consumption of fruits and vegetables.

\section{CONCLUSION}

Majority of respondents aged 56-65 years 22 people (48.7\%), results also showed that respondents who were male were 16 respondents (35.6\%) and women were 29 respondents (64.4\%). The majority of respondents' educational backgrounds appear in this study were Primary and secondary education (Elementary, junior high 
school, Senior High School) with 24 respondents (53.3\%). The majority of the working status of respondents in this study did not work with 28 respondents $(62.2 \%)$. The majority of respondents' knowledge in this study was good with 27 respondents $(60 \%)$. The results showed that respondents who had no anxiety 15 respondents $(33.3 \%)$, respondents with mild anxiety level 12 respondents $(26.7 \%)$, respondents with moderate anxiety level 12 respondents (26.7\%) and respondents with severe anxiety levels six respondents (13.3\%). There was no relationship between age and sex with anxiety in hypertensive patients. There is a relationship between education, work, and knowledge with anxiety hypertension patients.

The next researcher can multiply new variables that have not been studied in this study to find out which factors are the dominant factors causing anxiety in hypertensive patients who are undergoing treatment. Anxiety is directly related to an increase in blood pressure so that someone needs to do counseling related to his condition to reduce anxiety, and need changes from individuals to change the risk factors for hypertension with healthy lifestyles such as fruit, vegetables, exercise regularly and reduce excessive consumption of calories and

\section{References}

1. Kementerian Kesehatan RI. Profil Kesehatan Indonesia 2017. Profil Kesehat Indonesia 2017. 2018;100.

2. RI K. Hipertensi Faktor Risiko Utama Penyakit Kardiovaskular. 2009;7416.

3. Kementerian Kesehatan RI. InfoDATIN: Situasi dan Analisi Diabetes. 2014. p. 1-2.

4. Sawicka K, Szczyrek M, Jastrzębska I, Prasał M, Zwolak A, Daniluk J. Unknown 1982 segregation during directional melting and its implications on seeded crystal growrth.pdf - Unknown.pdf. 2011;5(2):43-6.

5. OMS. High Blood Pressure: The Silent Killer. World Heal Day [Internet]. 2013;(August):4. Available from: http://www.wpro.who.int/world_health_day/2013/high_blood_pressure_brochure _wpr.pdf

6. Singh T, Mawiong AM, Magh S. Association Of Anxiety Disorder With Hypertension And Coronary Heart disease : A Review. J Dent Med Sci. 2015;14(4):19-23.

7. Renna. Opinion New Guidelines for the Management of Hypertension: Much Controversy, the Good and the Not so Good. J Cardiol Cardiovasc Ther [Internet]. 2017;8(4):3-4.

8. Mubin MF, Hanum DM. Faktor-Faktor yang berhubungan dengan Kecemasan pada Anak usia Prasekolah di Bangsal Melati RSUD Tugurejo Semarang. 2007;

9. Ahsan, Retno L, Sriati. Faktor-Faktor yang Mempengaruhi Kecemasan Pre Operasi pada Pasien Sectio Caesarea di Ruang Instalasi Bedah Sentral RSUD Kanjuruhan Kepanjen Kabupaten Malang. EJournal UMM [Internet]. 2017;8:1-12.

10. Soedirman JK, Journal TS. Jurnal Keperawatan Soedirman (The Soedirman Journal of Nursing), Volume 10, No.2, Juli 2015. 2015;10(2):83-93.

11. Hamilton M. Hamilton Anxiety Rating Scale (HAM-A). Br J Med Psychol. 1959;32:505.

12. Setyaningsih MM, Setyowati S, Kuntarti K. Penurunan Kecemasan Ibu Hamil Risiko Tinggi Dalam Menghadapi Persalinan Melalui Paket "Harmoni." J Keperawatan Indonesia. 2013;16(3):176-82. 
13. Kang H, Smith M, Buckwalter KC, Ellingrod V, Schultz SK. Anxiety, Depression, and Cognitive Impairment in Dementia-Specific and Traditional Assisted Living. J Gerontol Nurs [Internet]. 2010;36(1):18-30.

14. Disano CL. Nurses ' Knowledge of Signs and Symptoms of Anxiety and Agitation. 2015;

15. Benaim C, Cailly B, Perennou D, Pelissier J. Validation of the aphasic depression rating scale. Stroke. 2004;35(7):1692-6.

16. Kjellgren KI, Svensson S, Ahlner J, Säljö R. Hypertensive patients' knowledge of high blood pressure. Scand J Prim Health Care. 1997;15(4):188-92.

17. Kurniawan MA. Faktor-Faktor yang Berhubungan dengan Tingkat Kecemasan Orang Tua Terkait Hospitalisasi Anak Usia Toddler di BRSD RAA Soewonso Pati. J Keperawatan. 2008;1(2):38-56.

18. Pramana KD, Okatiranti, Ningrum TP. Hubungan Tingkat Kecemasan Dengan Kejadian Hipertensi Di Panti Social Tresna Werdha Senjarawi Bandung. Ilmu Keperawatan. 2016;IV(2):116.

19. Bacon SL, Campbell TS, Arsenault A, Lavoie KL. The impact of mood and anxiety disorders on incident hypertension in one year. Int J Hypertens. 2014;2014.

20. Yunita L. Faktor-Faktor Yang Berhubungan Dengan Kejadian Prehipertensi Pada Usia Dewasa Di Wilayah Kerja Puskesmas Pelabuhan Sambas Kota Sibolga Tahun 2017. 2018.

21. Mungati M, Manangazira P, Takundwa L, Gombe NT, Rusakaniko S, Tshimanga M. Factors affecting diagnosis and management of hypertension in Mazowe District of Mashonaland Central Province in Zimbabwe: 2012. BMC Cardiovasc Disord. 2014;14(1):1-12.

22. Ftrina Y. Faktor-Faktor Yang Berhubungan Dengan Kejadian Hipertensi Pada Usia Lanjut Di Wilayah Kerja Puskesmas Kebun Sikolos Kecamatan Padang Panjang Barat Tahun 2014. Stikes Yarsi Sumbar Bukittinggi. 2014;(2002).

23. Larasiska A, Priyantari H.N W. Menurunkan Tekanan Darah dengan Cara Mudah Pada Lansia. Indonesia J Nurs Pract. 2017;1(2):55-63.

24. Ayada C, Toru, Korkut Y. The relationship of stress and blood pressure effectors. Hippokratia. 2015;19(2):99-108.

25. McCorry LK. Physiology of the \{Autonomic $\}$ \{Nervous\} \{System\}. Am J Pharm Educ [Internet]. 2007;71(4). Available from: http://www.ncbi.nlm.nih.gov/pmc/articles/PMC1959222/

26. Pandey M, Sarita GP, Devi N, Thomas BC, Hussain BM, Krishnan R. Distress, anxiety, and depression in cancer patients undergoing chemotherapy. World J Surg Oncol. 2006;4(February 2006).

27. Mansoor S, Jehangir S. Anxiety, depression in patients receiving chemotherapy for solid tumor S. 2015;65(1):89-93.

28. Jawaid M, Mushtaq A, Mukhtar S, Khan Z. Preoperative anxiety before elective surgery. Neurosciences. 2007;12(2):145-8.

29. Rinaldi PA, Opod, Pali C. Hubungan pengetahuan dengan tingkat kecemasan ibu yang anaknay di rawat rsup prof.dr.r.d.kandau manado. Junal e-Biomedik. 2013;1(November):1101-5.

30. Lu Y, Lu M, Dai H, Yang P, Smith-Gagen J, Miao R, et al. Lifestyle and risk of hypertension: Follow-up of a young pre-hypertensive cohort. Int J Med Sci. 2015;12(7):605-12.

31. Davies SJC, Hood SD, Christmas D, Nutt DJ. In: Psychological Factors and Cardiovascular Disorders: The Role of Psychiatric Pathology and Maladaptive 
Personality Features Psychiatric Disorders And Cardiovascular Disease Anxiety, Depression And Hypertension. 2008;1-28.

32. Sulastini, Fitria N. Hubungan Karakteristik Pasien Dengan Kecemasan Pada Pasien Gagal Jantung Kongestif Di Ruang Rawat Inap Rsu Dr. Slamet Garut. 2016;

33. Dahnil F, Mardhiyah A, Widianti E. NurseLine Journal. Nurseline J. 2017;2(1):1-10.

34. Vitasari P, Wahab MNA, Othman A, Herawan T, Sinnadurai SK. The relationship between study anxiety and academic performance among engineering students. Procedia - Soc Behav Sci. 2010;8(December):490-7.

35. Khodarahimi S, H. M. Hashim I, Mohd-Zaharim N. Workplace Relationships, Stress, Depression and Anxiety in a Malaysian Sample. Int J Psychol Behav Sci [Internet]. 2012;2(2):1-9.

36. Pamungkas RA, Kirana W, Florensa. Relaxation Progressive Muscle Program on Exercise Behavior and Clinical Outcomes among Hypertension Patients.

International Journal of Public Health Science (IJPHS). 2016; 5(4): 400-405

37. Roberge P, Fournier L, Brouillet H, Hudon C, Houle J, Provencher MD, et al. Implementing a knowledge application program for anxiety and depression in community-based primary mental health care: A multiple case study research protocol. Implement Sci. 2013;8(1):1-12. 